\title{
Effects of hydrothermal carbonization temperature on carbon retention, stability, and properties of animal manure-derived hydrochar
}

\author{
Feiyue $\mathrm{Li}^{\mathrm{i}^{* \dagger}}$, Zelun $\mathrm{J}$ iang $^{1 \dagger}$, Wenchao $\mathrm{Ji}^{1}$, Yihan Chen ${ }^{2}$, Jiran Ma ${ }^{1}$, Xiangyang Gui ${ }^{1}$, \\ J ianrong Zhao ${ }^{1}$, Chunhuo Zhou ${ }^{3 *}$ \\ (1. College of Resources and Environment Science, Anhui Science and Technology University, Fengyang 233100, Anhui, China; \\ 2. School of Resources and Environmental Engineering, Hefei University of Technology, Hefei 230009, China; \\ 3. College of Land Resources and Environment, Jiangxi Agricultural University, Nanchang 330045, China)
}

\begin{abstract}
Hydrothermal carbonization of animal manure is being increasingly recognized as a green process for hydrochar production. Temperature obviously affects the properties of hydrochar especially with respect to carbon retention and stability. These properties determine the carbon sequestration potential of hydrochar but related researches are limited. In this study, chicken, dairy, and swine manures were collected and hydrothermal carbonized under different temperature conditions, aiming to study the fuel characteristics, carbon retention, and stability of hydrochar influenced by temperature. Results show that high temperature led to low yield and declined $\mathrm{H} / \mathrm{C}, \mathrm{O} / \mathrm{C}$, and volatile matter of hydrochar. While high temperature caused high fixed carbon, fuel ratio, and heating value of hydrochar, indicating that animal manure hydrochar can be adopted as an alternative of fuel. After hydrothermal carbonization, less than half of carbon from animal manure was retained in hydrochar: $22.70 \%-46.71 \%$ for chicken manure, $39.36 \%-49.72 \%$ for dairy manure, and $36.24 \%-64.21 \%$ for swine manure. The carbon retention decreased with the increase of temperature. Conversely, high temperature improved the aromatic and strengthened the resistance to thermal oxidation of hydrochar, which was evidenced by FTIR and TGA analysis. Moreover, the carbon sequestration capacity of animal manure hydrochar was less than a third of total carbon (originated from animal manure) and relatively low temperature (no more than $250^{\circ} \mathrm{C}$ ) was beneficial to produce hydrochar for carbon sequestration.
\end{abstract}

Keywords: livestock manure, carbon sequestration, hydrochar, hydrothermal temperature

DOI: $10.25165 /$ j.jjabe. 20221501.6758

Citation: Li F Y, Jiang Z L, Ji W C, Chen Y H, Ma J R, Gui X Y, et al. Effects of hydrothermal carbonization temperature on carbon retention, stability, and properties of animal manure-derived hydrochar. Int J Agric \& Biol Eng, 2022; 15(1): 124-131.

\section{Introduction}

With the continuous development of animal husbandry, a large amount of animal manure is discharged. For example, the production of livestock manure in China is nearly 3 billion $t / a^{[1]}$. Many environmental and ecological problems including greenhouse gas emissions, water, and soil pollution are emerging $^{[2-4]}$. Hence, how to handle this manure is becoming urgent. In China, composting is a widely adopted method to treat animal manure. However, composting cannot effectively remove or immobilize antibiotics and heavy metals, which presents

Received date: 2021-05-12 Accepted date: 2021-12-07

Biographies: Zelun Jiang, BA, research interest: solid waste treatment, Email: 594063414@qq.com; Wenchao Ji, PhD, Assistant Professor, research interest: resource conversion of solid waste, Email: jiwc@ahstu.edu.cn; Yihan Chen, $\mathrm{PhD}$, Associate Professor, research interest: water pollution remediation, Email: yhchen@hfut.edu.cn; Jiran Ma, MS candidate, research interest: hydrothermal carbonization technology, Email: 1378931088@qq.com; Xiangyang Gui, PhD candidate, research interest: environmental pollution remediation, Email: xiangyanggui@163.com; Jianrong Zhao, MS, Associate Professor, research interest: agricultural solid waste recycling, Email: 653124657@qq.com.

$\uparrow$ These authors contributed equally to this work.

*Corresponding author: Feiyue Li, PhD, Professor, research interest: biochar production and application. College of Resources and Environment Science, Anhui Science and Technology University, Fengyang 233100, Anhui, China. Tel: +86-15905506793, Email: lify@ahstu.edu.cn; Chunhuo Zhou, PhD, Professor, research interest: agricultural solid waste recycling. College of Land Resources and Environment, Jiangxi Agricultural University, Nanchang 330045, China. Tel: +86-13970099796, Email: zchh3366@163.com. potential environmental and ecological risks and limits its utilization $^{[5-7]}$.

In the past decade, pyrolysis is considered a good approach for treating animal manure aiming to resolve the defects of compost ${ }^{[8-10]}$. The antibiotics are broken down and heavy metals are immobilized after pyrolysis ${ }^{[11-13]}$. Besides, manure-based biochar addition into soils brings extra environmental ecology benefits including soil quality improvement and soil pollution mitigation $^{[14-18]}$. However, pyrolysis requires a large amount of energy input and financial load ${ }^{[19,20]}$, in particular, for the pre-drying requirement of high-wet manure. Besides, many nutrients in manure are lost during the pyrolysis process under high-temperature conditions ${ }^{[21,22]}$. Moreover, the cost associated with the treatment and disposal of gas and liquid produced during the pyrolysis process limits its wide application ${ }^{[23]}$. Thus, developing a novel and efficient method for the disposal of animal manure is becoming an urgent issue.

At present, hydrothermal carbonization (HTC) conversion is gradually proved as a great method for the treatment of waste biomass. It is conducted at mild temperatures ${ }^{[23-25]}$. The necessity and advancement of HTC are 1) low energy input due to no pre-drying requirement for high-moisture waste biomass including sewage sludge and animal manure ${ }^{[26,27]}$; 2) clean production technology due to its smoke-free process and low hazardous gas discharge ${ }^{[28,29]}$; 3) mitigating environmental health risks by eliminating pollutants including pathogens, antibiotics and antibiotic resistance genes ${ }^{[30,31]}$; 4 ) multifunctional and high added 
value production including hydrochar and liquid ${ }^{[32,33]}$.

Hydrochar exhibits many advantages including high carbon and nutrient content, abundant functional groups, strong recalcitrance, high mass and energy density, etc. Hydrochar was widely applied including bioenergy production, wastewater pollution remediation, and exhaust gas purification ${ }^{[34-36]}$. Besides, hydrochar with high calorific values can serve as a potential fuel source $^{[37,38]}$. Moreover, the liquid as a by-product can be recycled and/or as a raw material for $\mathrm{CH}_{4}$ or fertilizer production ${ }^{[39,40]}$. In summary, HTC is an economically viable, environmentally friendly technology of hydrochar production for waste biomass disposal.

Feedstock and temperature greatly affect hydrochar properties $^{[35,41]}$. Many studies have focused on plant-based and slurry feedstock for hydrochar production ${ }^{[24,25,42]}$. Limited studies have considered animal manure including chicken, horse, rabbit and swine manures, etc. as a potential feedstock for $\mathrm{HTC}^{[43,44]}$. They have investigated the nutrients recovery and fixation, heavy metals species change and fuel characteristics of hydrochar. However, only a few studies have examined the carbon retention and stability of hydrochar influenced by temperature, especially with respect to its proposed use for carbon sequestration ${ }^{[45]}$. Hence, in this study, three animal manures were selected as feedstock at four temperatures for hydrochar production. The aims of this study include 1) study the temperature influenced the properties of hydrochar; 2) evaluate the energy potential of hydrochar; 3) determine the carbon retention, stability and carbon sequestration of hydrochar.

\section{Materials and methods}

\subsection{Materials}

Chicken manure, dairy manure, and swine manure were obtained from the suburbs of Bengbu City (China) as feedstock, air-dried, ground through a 20-mesh sieve for analysis and hydrochar production. The properties of the manure are shown in Table S1.

\subsection{Hydrochar production}

To obtain the animal manure based hydrochar, $20 \mathrm{~g}$ of each animal manure material and $200 \mathrm{~mL}$ of deionized water were placed in a $500 \mathrm{~mL}$ hydrothermal reactor (GS-0.5, Shandong Chemical Machinery Co., Ltd., China). Then the mixture in the reactor was stirred well, adjusted to approximately $\mathrm{pH}=7$, sealed with stainless steel cover, heated at a rate of $5^{\circ} \mathrm{C} / \mathrm{min}$ until it reached the four settled gradient temperatures from $200^{\circ} \mathrm{C}$ to $350^{\circ} \mathrm{C}$ and kept for $2 \mathrm{~h}$. After the hydrothermal reactor cooled down to room temperature through circulating water, the solid product was obtained by separating from the mixture in the reactor, dried at $105^{\circ} \mathrm{C}$ and labeled as hydrochar. For simplicity, the hydrochar was labeled as initial capital letters of feedstock and temperature, for example, C200 represents hydrochar derived from chicken manure under $200^{\circ} \mathrm{C}$.

\subsection{Characterization of hydrochar}

The element content, specific surface area, surface functional group distribution, morphology, and stability of hydrochar were analyzed using the authors' reported Methods [46-48].

\subsection{Calculation}

Carbon retention (CR) is defined as the quantity of carbon originated from carbon in feedstock and retained in the hydrochar and expressed as Equation (1) ${ }^{[49,50]}$

$$
\mathrm{CR}=\frac{C_{\text {hydrochar }}}{C_{\text {feedstock }}} \times \text { Yield }
$$

where, $C_{\text {hydrochar }}$ and $C_{\text {feedstock }}$ are carbon content of hydrochar and animal manure, respectively, $\%$; Yield is the hydrochar yield, $\%$.

$R_{50}$ is an index used to express the recalcitrance of carbon in the hydrochar as Equation (2).

$$
R_{50}=\frac{T_{50, \text { hydrochar }}}{T_{50, \text { graphite }}}
$$

where, $T_{50 \text {, hydrochar }}$ and $T_{50 \text {, graphite }}$ are the temperature values when $50 \%$ weight of hydrochar and graphite loss based on TGA analysis $^{[45,51]}$

The high heating value ( $\mathrm{HHV}, \mathrm{MJ} / \mathrm{kg}$ ) was calculated using Equation (3).

$\mathrm{HHV}=0.3491 C_{w}+1.1783 H_{w}-0.1034 O_{w}-0.0151 N_{w}-0.211$ Ash (3) where, $C_{w}, H_{w}, O_{w}$, and $N_{w}$ are the mass percentages for $\mathrm{C}, \mathrm{H}, \mathrm{O}$ and $\mathrm{N}$ of hydrochar or its feedstock, respectively; Ash is the mass percentages of hydrochar or its feedstock.

The energy densification (ED) and the energy yield (EY) were calculated using Equations (4) and (5), respectively.

$$
\begin{aligned}
& \mathrm{ED}=\frac{\mathrm{HHV}_{\text {hydrochar }}}{\mathrm{HHV}_{\text {feedstock }}} \\
& \mathrm{EY}=\mathrm{ED} \cdot \text { Yield }
\end{aligned}
$$

where, $\mathrm{HHV}_{\text {hydrochar }}$ and $\mathrm{HHV}_{\text {feedstock }}$ are the high heating values of hydrochar and its feedstock, respectively.

\section{Results and discussion}

\subsection{Yield and ultimate analysis}

As shown in Table 1, the yield of hydrochar declined with the temperature increase. The $\mathrm{C}$ contents of hydrochar were high and increased with the temperature rise indicating that HTC played an important role in carbon enrichment depending on the temperature. It is consistent with other reported results ${ }^{[52,53]}$.

Table 1 Elemental compositions of animal manures and their hydrochar

\begin{tabular}{ccccccccc}
\hline Sample & Yield/\% & $\mathrm{C} / \%$ & $\mathrm{H} / \%$ & $\mathrm{~N} / \%$ & $\mathrm{O} / \%$ & $\mathrm{Ash} / \%$ & $\mathrm{H} / \mathrm{C}$ & $\mathrm{O} / \mathrm{C}$ \\
\hline Chicken manure & -- & 41.27 & 6.43 & 3.55 & 37.15 & 11.60 & 1.87 & 0.68 \\
C200 & 42.41 & 46.34 & 5.82 & 2.70 & 21.58 & 23.56 & 1.51 & 0.35 \\
C250 & 20.97 & 48.69 & 5.53 & 2.86 & 10.68 & 32.24 & 1.36 & 0.16 \\
C300 & 18.41 & 50.87 & 5.77 & 2.72 & 5.87 & 34.76 & 1.36 & 0.09 \\
C350 & 21.46 & 53.71 & 5.83 & 2.81 & 6.63 & 31.02 & 1.30 & 0.09 \\
Dairy manure & -- & 35.99 & 4.98 & 0.67 & 47.61 & 10.75 & 1.66 & 0.99 \\
D200 & 41.77 & 42.84 & 5.11 & 1.12 & 31.12 & 19.82 & 1.43 & 0.54 \\
D250 & 32.74 & 48.21 & 4.18 & 2.01 & 16.45 & 29.15 & 1.04 & 0.26 \\
D300 & 29.75 & 48.47 & 3.73 & 2.14 & 11.78 & 33.87 & 0.92 & 0.18 \\
D350 & 25.66 & 55.22 & 4.46 & 2.37 & 10.04 & 27.91 & 0.97 & 0.14 \\
Swine manure & -- & 39.22 & 5.47 & 1.37 & 41.36 & 12.58 & 1.67 & 0.79 \\
S200 & 55.52 & 45.36 & 5.23 & 1.28 & 29.46 & 18.67 & 1.38 & 0.49 \\
S250 & 37.37 & 48.99 & 4.80 & 1.86 & 17.05 & 27.30 & 1.18 & 0.26 \\
S300 & 30.89 & 49.62 & 4.30 & 2.11 & 10.72 & 33.25 & 1.04 & 0.16 \\
S350 & 25.64 & 55.45 & 4.43 & 2.30 & 8.47 & 29.35 & 0.96 & 0.11 \\
\hline
\end{tabular}

Note: $\mathrm{O}=100-\mathrm{C}-\mathrm{H}-\mathrm{N}-$ Ash. For simplicity, the hydrochar was labeled as initial capital letters of feedstock and temperature, for example, C200 represents hydrochar derived from chicken manure under $200^{\circ}$ C. D: Dairy; S: Swine.

Noticeably, the oxygen content of hydrochar sharply decreased with the rise in temperature from $21.85 \%$ to $6.63 \%, 31.12 \%$ to $10.04 \%, 29.46 \%$ to $8.47 \%$ for chicken, dairy, and swine manure based hydrochar, respectively. Moreover, the oxygen content of hydrochar much lower than that of its feedstock indicates that during the HTC process the oxygen-containing component probably broken down and its products diffused into liquid phase and/or escaped into the gas phase. The phenomenon is consistent with other reports ${ }^{[23,35]}$. 
The hydrogen contents of hydrochar somewhat declined with the temperature increase $\left(200^{\circ} \mathrm{C}-300^{\circ} \mathrm{C}\right)$. When the temperature reached $350^{\circ} \mathrm{C}$, its contents increased. However, the trend of nitrogen content with temperature depended on the type of animal manure. On one hand, for the chicken manure hydrochar, its nitrogen content decreased slightly. On the other hand, for dairy and swine manure hydrochar, their nitrogen contents gradually increased and enriched.

$\mathrm{H} / \mathrm{C}$ and $\mathrm{O} / \mathrm{C}$ ratios are two indexes for evaluating the carbon aromaticity of carbon-based material ${ }^{[25,54]}$. With the rise of temperature, the $\mathrm{H} / \mathrm{C}$ ratio and $\mathrm{O} / \mathrm{C}$ ratio of hydrochar gradually decreased, which is consistent with findings of other studies ${ }^{[55,56]}$, indicating that high temperature promoted the aromaticity of hydrochar.

\subsection{Proximate analysis and energy content}

In this study, the ash content of hydrochar gradually increased from $200^{\circ} \mathrm{C}$ to $300^{\circ} \mathrm{C}$. While it decreased at temperatures over $300^{\circ} \mathrm{C}$ (Table 1) probably due to the mineral matter, decomposing under high temperature and/or promoting the mineral diffuse into liquid. As temperature increased, the labile organic component originated from feedstock decomposed and formed some fragments dissolving in the liquid phase, meanwhile, these fragments could also turn into insoluble solids by polymerization ${ }^{[23]}$, which led to decreased volatile matter (VM) and increased fixed carbon (FC) (Table 2). Moreover, the FC of chicken manure-based hydrochar was much lower than that of the other two manure-based hydrochar, in particular, when the hydrothermal temperature was over $200^{\circ} \mathrm{C}$, indicating that the FC of hydrochar depended on feedstock type.

Table 2 Proximate analysis and thermal dynamic properties of animal manures and their hydrochar

\begin{tabular}{ccccccccc}
\hline Sample & $\begin{array}{c}\text { VM } \\
/ \%\end{array}$ & $\begin{array}{c}\text { FC } \\
/ \%\end{array}$ & $\begin{array}{c}\text { Fuel } \\
\text { ratio }\end{array}$ & $\begin{array}{c}\mathrm{HHV} \\
/ \mathrm{MJ} \cdot \mathrm{kg}^{-1}\end{array}$ & $\mathrm{ED}$ & $\begin{array}{c}\mathrm{EY} \\
/ \%\end{array}$ & $\begin{array}{c}\mathrm{CR} \\
/ \%\end{array}$ & $\mathrm{R}_{50}$ \\
\hline Chicken manure & 82.54 & 5.86 & 0.07 & 15.64 & -- & -- & -- & 0.45 \\
C200 & 67.20 & 9.24 & 0.14 & 15.79 & 1.01 & 42.81 & 47.61 & 0.50 \\
C250 & 56.44 & 11.32 & 0.20 & 15.56 & 0.99 & 20.86 & 24.74 & 0.55 \\
C300 & 49.50 & 15.74 & 0.32 & 16.58 & 1.06 & 19.52 & 22.70 & 0.60 \\
C350 & 54.36 & 14.62 & 0.27 & 18.34 & 1.17 & 25.17 & 27.93 & 0.64 \\
Dairy manure & 88.00 & 1.25 & 0.01 & 11.24 & -- & -- & -- & 0.44 \\
D200 & 74.67 & 5.51 & 0.07 & 13.55 & 1.21 & 50.37 & 49.72 & 0.46 \\
D250 & 38.36 & 32.49 & 0.85 & 13.88 & 1.23 & 40.42 & 43.85 & 0.60 \\
D300 & 32.42 & 33.71 & 1.04 & 12.93 & 1.15 & 34.21 & 40.07 & 0.64 \\
D350 & 30.57 & 41.52 & 1.36 & 17.56 & 1.56 & 40.09 & 39.36 & 0.63 \\
Swine manure & 82.97 & 4.45 & 0.05 & 13.18 & -- & -- & -- & 0.42 \\
S200 & 65.60 & 15.73 & 0.24 & 14.99 & 1.14 & 63.15 & 64.21 & 0.48 \\
S250 & 50.71 & 21.99 & 0.43 & 15.21 & 1.15 & 43.12 & 46.68 & 0.55 \\
S300 & 38.01 & 28.74 & 0.76 & 14.23 & 1.08 & 33.36 & 39.08 & 0.61 \\
S350 & 33.39 & 37.26 & 1.12 & 17.47 & 1.33 & 33.98 & 36.24 & 0.62 \\
\hline
\end{tabular}

Note: FC=100-VM-Ash; Fuel ratios=FC/VM. VM: Volatile matter; FC: Fixed carbon; HHV: High heating value; ED: Energy densification; EY: Energy yield; CR: Carbon retention; $R_{50}$ is an index used to express the recalcitrance of carbon in the hydrochar.

As shown in Table 2, the fuel ratio of animal manure was too low to be used as an alternative of fuel. However, after it was hydrothermal carbonization, the fuel ratio of hydrochar showed an increasing trend, in particular, it was over 1 when the temperature was over $300^{\circ} \mathrm{C}$ for dairy and swine manure-based hydrochar, implying high temperature was beneficial for improving the fuel ratio and these two kinds of hydrochar could be an alternative fuel. However, the fuel ratios of all the chicken manure-based hydrochar were too small to fit as an alternative to fuel.

The HHV of hydrochar depended on the feedstock and temperature. For the chicken-manure hydrochar, the HHV slightly changed, until the temperature reached $350^{\circ} \mathrm{C}$, increased $16.15 \%$, compared to $\mathrm{C} 200$. For the dairy and swine manure-based hydrochar, the HHV gradually increased with the rise of temperature except under $300^{\circ} \mathrm{C}$, which had the lowest HHV. During the hydrothermal, with the temperature increase, hemi-cellulosic components relatively rich in $\mathrm{O}$ content decreased and lignin relatively rich in $\mathrm{C}$ content components increased in hydrochar led to HHV gradually increased ${ }^{[52,57]}$. Then temperature reached a critical temperature, due to the increase of mineral content and some carbon loss, the HHV sharply decreased. When temperature continued to rise, the density and aromaticity of carbon strengthened by polymerization to the highest $\mathrm{HHV}^{[26,58]}$. Moreover, the trend of ED and EY was as similar as that of HHV. The EY of dairy and swine manure-based hydrochar was much higher than that of chicken-manure hydrochar. All of these indicate that chicken-manure was unfit to be turned into hydrochar with the purpose of fuel alternative.

\subsection{SEM analysis}

Scanning electron microscope (SEM) images were used to investigate surface morphology evolutions of hydrochar at different hydrothermal carbonization temperatures from $200^{\circ} \mathrm{C}$ to $350^{\circ} \mathrm{C}$. The morphology of hydrochar from low temperatures (especially for C200, D200, and S200) was of the tight block structure and clustered aggregates originating from animal manure feedstock without porous structure or pathways (Figure S1). With the temperature rising, the fragmentation and porosity of hydrochars increased especially for the highest temperature derived hydrochars (C350, D350, and S350). High temperature promoting the release of volatile matter by devolatilization and chemical bond decomposition of animal manure matrix led to its porous structure formation $^{[59]}$.

\subsection{FTIR analysis}

The Fourier Transform Infrared Spectroscopy (FTIR) of animal manure hydrochar is presented in Figure 1. There were five main vibration regions as follows: $3381-3425 \mathrm{~cm}^{-1}$, 2845-2924 $\mathrm{cm}^{-1}, \quad 1692-1720 \mathrm{~cm}^{-1}, \quad 1455-1661 \mathrm{~cm}^{-1}$, $1067-1103 \mathrm{~cm}^{-1}$, which correspond to $-\mathrm{OH}, \mathrm{C}-\mathrm{H}_{x}, \mathrm{C}=\mathrm{O}, \mathrm{C}=\mathrm{C}$, and C-O vibrations, respectively ${ }^{[60-62]}$. With the temperature increasing, the $-\mathrm{OH}$ sharply decreased and even up to disappear probably attributed to the dehydration during the HTC, which is in accord with other reports ${ }^{[23,45]}$. However, the $\mathrm{C}-\mathrm{H}_{x}$ and $\mathrm{C}=\mathrm{O}$ vibration strength improved, as the temperature rose. Besides, a similar trend was found for $\mathrm{C}=\mathrm{C}$ vibrations, indicating that the aromatic nature of hydrochar improved that is in accord with the $\mathrm{O} / \mathrm{C}$ and $\mathrm{H} / \mathrm{C}$ atomic ratio changing trendy (Table 1 ). Usually, the higher the aromatic degree is, the more stable is the hydrochar ${ }^{[49,63]}$. Hence, the stability of hydrochar was strengthened by increasing temperature. Moreover, the $\mathrm{C}-\mathrm{O}$ vibrations improved with increased temperature for chicken and dairy manure hydrochar, while the opposite result was for swine manure hydrochar (Figure 1). The FTIR spectra showed hydrochar was rich in oxygen-containing functional groups.

\subsection{TGA analysis}

As shown in Figure 2, when the temperature was below $220^{\circ} \mathrm{C}$, there was an obvious weight loss peak of the chicken-manure and its hydrochar, the opposite to that of the other two kinds of hydrochar. During the hydrothermal process, some small and liable molecule organics and/or some undecomposed hemicellulose are sequestrated in hydrochar, usually, the weight loss of hemicellulose mainly happens at $220^{\circ} \mathrm{C}-315^{\circ} \mathrm{C}^{[64]}$, and they can release and/or decomposition from the hydrochar under heated with 
air. It was further supported by proximate analysis (Table 2) that chicken manure hydrochar showed high VM content. From $220^{\circ} \mathrm{C}$ to $500^{\circ} \mathrm{C}$, the majority weight loss of the hydrochar happened. The stage can be divided into two main regions, one was below about $375^{\circ} \mathrm{C}$ and the other was over $375^{\circ} \mathrm{C}$ which can be ascribed to the oxidation of volatile matter fixed carbon, respectively ${ }^{[30]}$. Moreover, hydrochar derived from over $300^{\circ} \mathrm{C}$ showed little weight loss in the region below $375^{\circ} \mathrm{C}$, the weight loss of cellulose mainly happens during this region ${ }^{[64]}$. Moreover, the weight loss of the modified hydrochar was much lower than that of pristine hydrochar. When the temperature was over $500^{\circ} \mathrm{C}$, there was no obvious change in hydrochar weight loss.

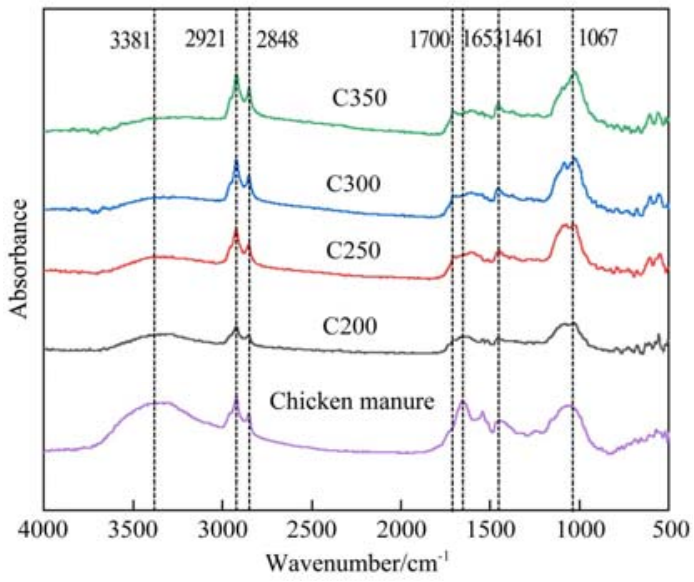

a. Chicken manure and its hydrochar

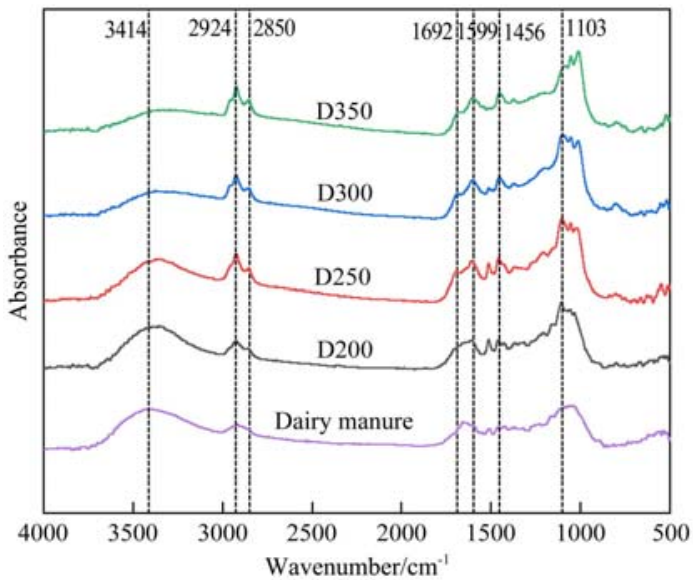

b. Dairy manure and its hydrochar

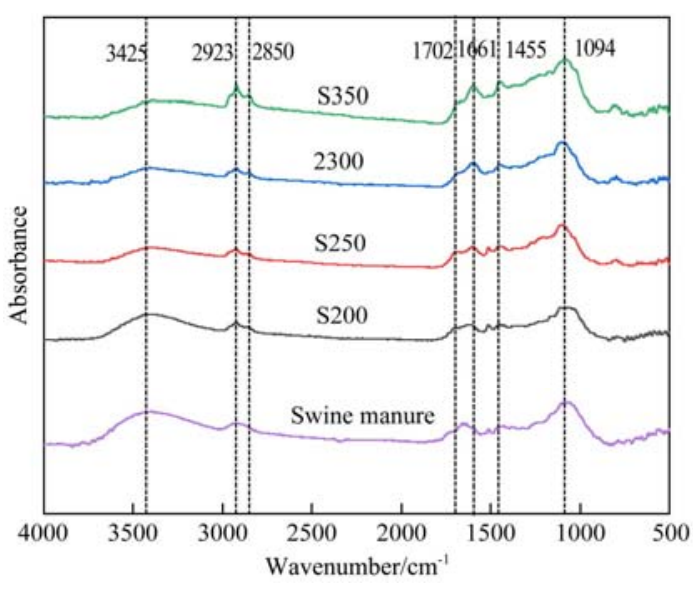

c. Swine manure and its hydrochar

Note: For simplicity, the hydrochar was labeled as initial capital letters of feedstock and temperature, for example, $\mathrm{C} 200$ represents hydrochar derived from chicken manure under $200^{\circ} \mathrm{C}$. D: Dairy; S: Swine.

Figure 1 FTIR of animal manure and its hydrochar

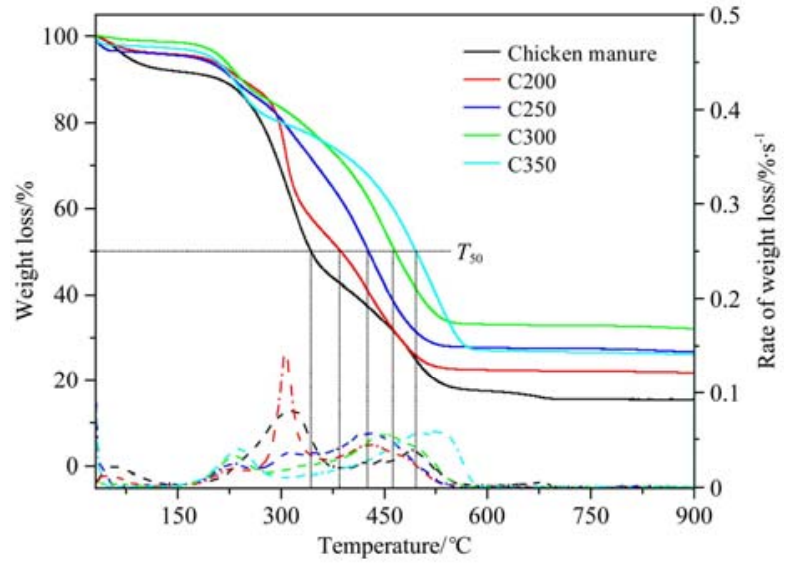

a. Chicken manure and its hydrochar

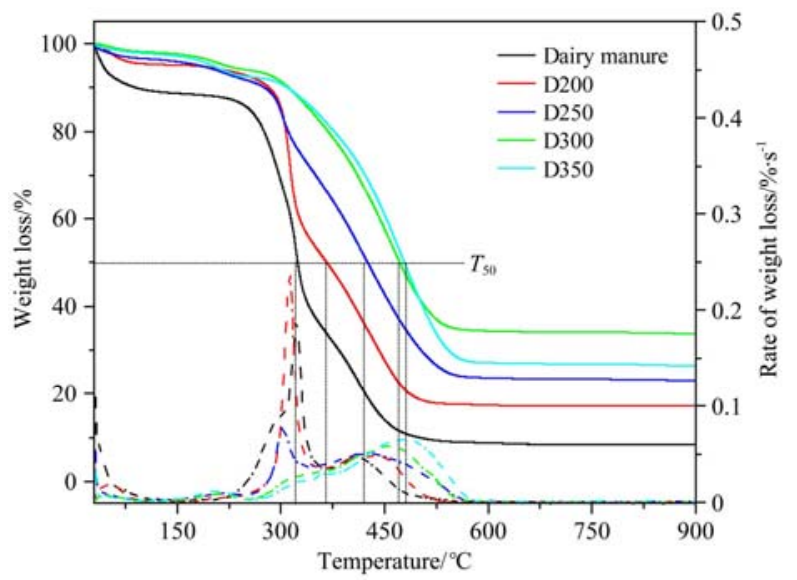

b. Dairy manure and its hydrochar

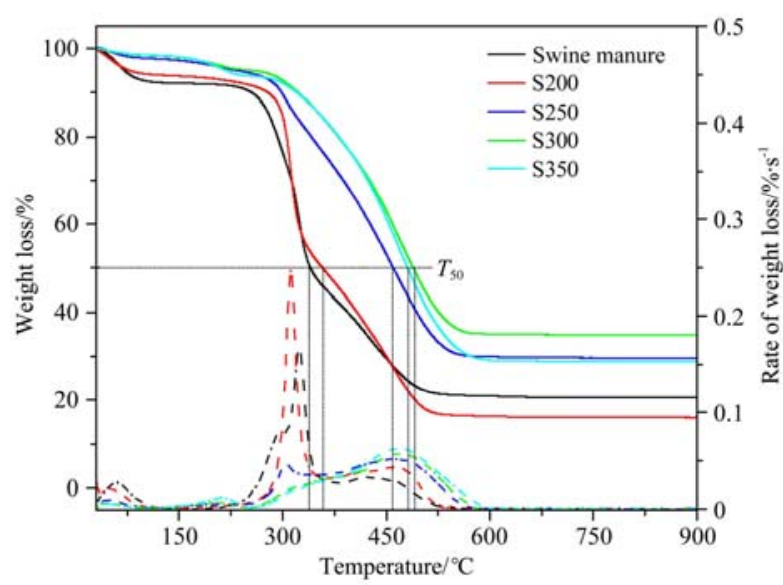

c. Swine manure and its hydrochar

Figure 2 TGA of animal manure and its hydrochar

\subsection{Carbon retention and stability}

Carbon retention was a very important characteristic of hydrochar meaning that the carbon element from feedstock was retained after turning into hydrochar. The more carbon sequestered in the hydrochar, there is less greenhouse gas emission $\left(\mathrm{CO}, \mathrm{CO}_{2}\right.$, and $\left.\mathrm{CH}_{4}\right)$ and organic liquid discharge. In this study, low temperature was beneficial for the increase of carbon retention (Table 2) and it decreased with the increase of temperature (except $\mathrm{C} 350$ ). When the temperature was $200^{\circ} \mathrm{C}$, over half of carbon was retained in the hydrochar (except C200), and the temperature was over $200^{\circ} \mathrm{C}$, the average of carbon retention was about $25 \%$ for chicken manure hydrochar and $40 \%$ for dairy manure and swine manure hydrochar. Moreover, the carbon retention also depended on the type of animal manure. The chicken manure hydrochar contained much lower carbon retention than that of the others, in 
particular, hydrochar obtained under high temperature due to its high volatile matter content (Table 2).

Carbon stability is another key characteristic of hydrochar that determined its life cycle. Because the $\mathrm{H} / \mathrm{C}$ and $\mathrm{O} / \mathrm{C}$ can reflect the aromatic nature of biochar and high aromatic means strong stability, they are widely adopted as an index to evaluate the stability of biochar ${ }^{[65,66]}$. Hydrochar belongs to biochar. $R_{50}$, another index, is used to express resistance to thermal oxidation of biochar and shows its stability ${ }^{[1]}$. In this study, with temperature increased, the $R_{50}$ of hydrochar gradually rise. Moreover, there was a significant $(p<0.01)$ relationship between the $R_{50}$ and $\mathrm{H} / \mathrm{C}$ and $\mathrm{O} / \mathrm{C}$ (Figure 3), indicating that $R_{50}$ was a simple and effective index to estimate carbon stability.

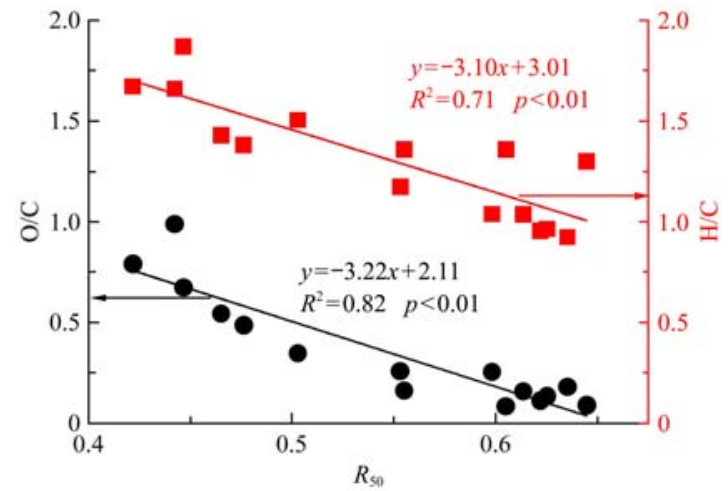

Note: The black arrow means the linear equation between the $\mathrm{O} / \mathrm{C}$ and $\mathrm{R}_{50}$; the red arrow means the linear equation between the $\mathrm{H} / \mathrm{C}$ and $\mathrm{R}_{50}$.

Figure 3 Correlations between $\mathrm{R}_{50}$ of hydrochar and elemental composition characteristics of hydrochar $(\mathrm{H} / \mathrm{C}$ and $\mathrm{O} / \mathrm{C})$

Hydrothermal carbonization of animal manure into hydrochar is considered a promising method for sequestering carbon to alleviate climate change when returned to the soil ${ }^{[67,68]}$. Usually, hydrochar with high carbon retention and strong carbon stability exhibits excellent carbon sequestration potential, which depends on the temperature and feedstock ${ }^{[33,49]}$. However, in our study, carbon retention of hydrochar decreased with the temperature increase while the opposite change trend for carbon stability (Table 2). In order to accurately evaluate the effect of temperature on the carbon sequestration potential of hydrothermal carbon, the carbon sequestration (CS) index was adopted ${ }^{[51]}$.

$$
\mathrm{CS}=\mathrm{CR} \cdot R_{50}
$$

Carbon sequestration was calculated in Figure S2. It showed that with the temperature increased, the carbon sequestration varied from $13.6 \%$ to $23.8 \%$ for chicken manure-derived hydrochar, $22.9 \%$ to $26.3 \%$ for dairy manure-derived hydrochar and $22.5 \%$ to $30.8 \%$ for swine manure-derived hydrochar, respectively. Moreover, the optimal processing temperature for maximum carbon sequestration in hydrochar was $200^{\circ} \mathrm{C}$ for chicken manure and swine manure, and $250^{\circ} \mathrm{C}$ for dairy manure, indicating that low temperature was beneficial for carbon sequestration and hydrothermal carbonization of animal manure into hydrochar was a promising tool for carbon sequestration.

\section{Conclusions}

The properties of hydrochar derived from animal manure varied at different temperatures. With increasing temperature, the yield, $\mathrm{H} / \mathrm{C}, \mathrm{O} / \mathrm{C}$, and $\mathrm{VM}$ of hydrochar decreased, however, the fixed carbon, HHV, and fuel ratio increased. High temperature improved the aromaticity of hydrochar and strengthened its stability but reduced carbon retention. $R_{50}$ was an effective index to estimate the carbon stability of animal manure hydrochar. In addition, relatively low temperature $\left(\leq 250^{\circ} \mathrm{C}\right)$ was beneficial for hydrochar production to sequestrate carbon.

\section{Acknowledgements}

The authors would like to acknowledge the support of the Anhui Science and Technology Major Project (Grant No. 201903a06020023), the Natural Science Research Project of Colleges and Universities in Anhui Province (Grant No. KJ2020A0049), the Anhui Province University Top Talent Funding Project (Grant No. gxbjZD2021069), the Commissioned R\&D Project (Grant No. ZHEP2021001; No. BOFA202007).

\section{[References]}

[1] Chen G Y, He S R, Cheng Z J, Guan Y N, Yan B B, Ma W C, et al Comparison of kinetic analysis methods in thermal decomposition of cattle manure by themogravimetric analysis. Bioresource Technology, 2017; 243: 69-77.

[2] Sakadevan K, Nguyen M L. Livestock production and its impact on nutrient pollution and greenhouse gas emissions. In: Advances in agronomy. Academic Press, 2017; 141: 147-184.

[3] Leip A, Billen G, Garnier J, Grizzetti B, Lassaletta L, Reis S, et al. Impacts of European livestock production: Nitrogen Sulphur phosphorus and greenhouse gas emissions, land-use, water eutrophication and biodiversity. Environmental Research Letters, 2016; 10(11): 115004. doi: 10.1088/1748-9326/10/11/115004.

[4] Ghaly A E, Ramakrishnan V V. Nitrogen sources and cycling in the ecosystem and its role in air, water and soil pollution: A critical review. Journal of Pollution Effects \& Control, 2015; 3(2): $1000136 . \quad$ doi: 10.4172/2375-4397.1000136.

[5] He Z Q, Pagliari P H, Waldrip H M. Applied and environmental chemistry of animal manure: A review. Pedosphere, 2016; 26(6): 779-816.

[6] Martinez J, Dabert P, Barrington S, Burton C. Livestock waste treatment systems for environmental quality, food safety, and sustainability. Bioresource Technology, 2009; 100(22): 5527-5536.

[7] Guo T, Lou C L, Zhai W W, Tang X J, Hashmi M Z, Murtaza R, et al. Increased occurrence of heavy metals, antibiotics and resistance genes in surface soil after long-term application of manure. Science of the Total Environment, 2018; 635: 995-1003.

[8] Wu H P, Lai C, Zeng G M, Liang J, Chen J, Xu J J, et al. The interactions of composting and biochar and their implications for soil amendment and pollution remediation: a review. Critical Reviews in Biotechnology, 2017; 37(6): 754-764.

[9] Cui E P, Wu Y, Zuo Y R, Chen H. Effect of different biochars on antibiotic resistance genes and bacterial community during chicken manure composting. Bioresource Technology, 2016; 203: 11-17.

[10] Zhou X, Qiao M, Su J Q, Wang Y, Cao Z H, Cheng W D, et al. Turning pig manure into biochar can effectively mitigate antibiotic resistance genes as organic fertilizer. Science of the Total Environment, 2019; 649: 902-908.

[11] Tian R Q, Li C X, Xie S Y, You F T, Cao Z H, Xu Z H, et al. Preparation of biochar via pyrolysis at laboratory and pilot scales to remove antibiotics and immobilize heavy metals in livestock feces. Journal of Soils and Sediments, 2019; 19: 2891-2902.

[12] Meng J, Liang S J, Tao M M, Liu X M, Brookes P C, Xu J M. Chemical speciation and risk assessment of $\mathrm{Cu}$ and $\mathrm{Zn}$ in biochars derived from co-pyrolysis of pig manure with rice straw. Chemosphere, 2018; 200 : 344-350.

[13] Lin Q, Liang L, Wang L H, Ni Q L, Yang K, Zhang J, et al. Roles of pyrolysis on availability, species and distribution of $\mathrm{Cu}$ and $\mathrm{Zn}$ in the swine manure: chemical extractions and high-energy synchrotron analyses. Chemosphere, 2013; 93(9): 2094-2100.

[14] Maroušek J, Strunecký O, Stehel V. Biochar farming: Defining economically perspective applications. Clean Technologies and Environmental Policy, 2019; 21(7): 1389-1395.

[15] Cao X D, Harris W. Properties of dairy-manure-derived biochar pertinent to its potential use in remediation. Bioresource Technology, 2010; 101(14): 5222-5228.

[16] Agegnehu G, Srivastava A K, Bird M I. The role of biochar and biochar-compost in improving soil quality and crop performance: a review. 
Applied Soil Ecology, 2017; 119: 156-170.

[17] Lu L, Yu W T, Wang Y F, Zhang K, Zhu X M, Zhang Y C, et al., Application of biochar-based materials in environmental remediation: from multi-level structures to specific devices. Biochar, 2020; 2: 1-31.

[18] Zheng Y L, Wan Y S, Chen J J, Chen H, Gao B. MgO modified biochar produced through ball milling: A dual-functional adsorbent for removal of different contaminants. Chemosphere, 2020; 243: 125344. doi: 10.1016/j.chemosphere.2019.125344.

[19] Benavente V, Calabuig E, Fullana A. Upgrading of moist agro-industrial wastes by hydrothermal carbonization. Journal of Analytical and Applied Pyrolysis, 2015; 113: 89-98.

[20] Escala M, Zumbuhl T, Koller C, Junge R, Krebs R. Hydrothermal carbonization as an energy-efficient alternative to established drying technologies for sewage sludge: a feasibility study on a laboratory scale. Energy \& Fuels, 2013; 27(1): 454-460.

[21] Zornoza R, Moreno-Barriga F, Acosta J A, Muñoz M A, Fazet A. Stability, nutrient availability and hydrophobicity of biochars derived from manure, crop residues, and municipal solid waste for their use as soil amendments. Chemosphere, 2016; 144: 122-130.

[22] Cantrell K B, Hunt P G, Uchimiya M, Novak J M, Ro K S. Impact of pyrolysis temperature and manure source on physicochemical characteristics of biochar. Bioresource Technology, 2012; 107: 419-428.

[23] Zhang Y, Jiang Q, Xie W L, Wang Y F, Kang J M. Effects of temperature, time and acidity of hydrothermal carbonization on the hydrochar properties and nitrogen recovery from corn stover. Biomass and Bioenergy, 2019; 122: $175-182$.

[24] Lee J, Sohn D, Lee K, Park K Y. Solid fuel production through hydrothermal carbonization of sewage sludge and microalgae Chlorella sp. from wastewater treatment plant. Chemosphere, 2019; 230: 157-163.

[25] Yao Z L, Ma X Q. Hydrothermal carbonization of Chinese fan palm. Bioresource Technology, 2019; 282: 28-36.

[26] Lang Q Q, Luo H N, Li Y, Li D, Liu Z Q, Yang T X. Thermal behavior of hydrochar from co-hydrothermal carbonization of swine manure and sawdust: effect of process water recirculation. Sustainable Energy \& Fuels, 2019; 3: 2329-2336.

[27] Zhai Y B, Liu X M, Zhu Y, Peng C, Wang T F, Zhu L, et al. Hydrothermal carbonization of sewage sludge: The effect of feed-water $\mathrm{pH}$ on fate and risk of heavy metals in hydrochars. Bioresource Technology, 2016; 218: 183-188.

[28] Kambo H S, Dutta A. A comparative review of biochar and hydrochar in terms of production, physico-chemical properties and applications. Renewable and Sustainable Energy Reviews, 2015; 45: 359-378.

[29] Yu S, Feng Y F, Xue L H, Sun H J, Han L F, Yang L Z, et al. Biowaste to treasure: Application of microbial-aged hydrochar in rice paddy could improve nitrogen use efficiency and rice grain free amino acids. Journal of Cleaner Production, 2019; 240: 118180. doi: 10.1016/j.jclepro.2019. 118180 .

[30] Lang Q Q, Chen M J, Guo Y C, Liu Z G, Gai C. Effect of hydrothermal carbonization on heavy metals in swine manure: speciation, bioavailability and environmental risk. Journal of Environmental Management, 2019; 234: 97-103.

[31] Ducey T F, Collins J C, Ro K S, Woodbury B L, Griffin D D. Hydrothermal carbonization of livestock mortality for the reduction of pathogens and microbially-derived DNA. Frontiers of Environmental Science \& Engineering, 2017; 11: 9. doi: 10.1007/s11783-017-0930-x.

[32] Chen C, Liu G M, An Q, Lin L, Shang Y, Wan C L. From wasted sludge to valuable biochar by low temperature hydrothermal carbonization treatment: Insight into the surface characteristics. Journal of Cleaner Production, 2020; 263: 121600. doi: 10.1016/j.jclepro.2020.121600.

[33] Liu Y Y, Ma S Q, Chen J W. A novel pyro-hydrochar via sequential carbonization of biomass waste: Preparation, characterization and adsorption capacity. Journal of Cleaner Production, 2018; 176: 187-195.

[34] Reibe K, Götz K P, Roß C L, Döring T F, Ellmer F, Ruess L. Impact of quality and quantity of biochar and hydrochar on soil Collembola and growth of spring wheat. Soil Biology and Biochemistry, 2015; 83: 84-87.

[35] Wang T F, Zhai Y B, Y. Zhu, Li C T, Zeng G M. A review of the hydrothermal carbonization of biomass waste for hydrochar formation: Process conditions, fundamentals, and physicochemical properties. Renewable and Sustainable Energy Reviews, 2018; 90: 223-247.

[36] Liu Y X, Gao C X, Wang Y T, He L L, H H Lu, Yang S M. Vermiculite modification increases carbon retention and stability of rice straw biochar at different carbonization temperatures. Journal of Cleaner Production, 2020; 254: 120111. doi: 10.1016/j.jclepro.2020.120111.
[37] Mau V, Gross A. Energy conversion and gas emissions from production and combustion of poultry-litter-derived hydrochar and biochar. Applied Energy, 2018; 213: 510-519.

[38] Román S, Nabais J M V, Laginhas C, Ledesma B, González J F. Hydrothermal carbonization as an effective way of densifying the energy content of biomass. Fuel Processing Technology, 2012; 103: 78-83.

[39] Smith A M, Ross A B. Production of bio-coal, bio-methane and fertilizer from seaweed via hydrothermal carbonisation. Algal Research, 2016; 16: $1-11$.

[40] Wirth B, Reza T, Mumme J. Influence of digestion temperature and organic loading rate on the continuous anaerobic treatment of process liquor from hydrothermal carbonization of sewage sludge. Bioresource Technology, 2015; 198: 215-222.

[41] Sun Y Y, Gao B, Yao Y, Fang J, Zhang M, Zhou Y M, et al. Effects of feedstock type, production method, and pyrolysis temperature on biochar and hydrochar properties. Chemical Engineering Journal, 2014; 240: 574-578.

[42] Oliveira I, Blöhse D, Ramke H G. Hydrothermal carbonization of agricultural residues. Bioresource Technology, 2013; 142: 138-146.

[43] Heilmann S M, Molde J S, Timler J G, Wood B M, Mikula A L, Vozhdayev $\mathrm{G} \mathrm{V}$, et al. Phosphorus reclamation through hydrothermal carbonization of animal manures. Environmental Science \& Technology, 2014; 48(17): 10323-10329.

[44] Lang Q Q, Guo Y C, Zheng Q F, Liu Z G, Gai C. Co-hydrothermal carbonization of lignocellulosic biomass and swine manure: Hydrochar properties and heavy metal transformation behavior. Bioresource Technology, 2018; 266: 242-248.

[45] Zhu X D, Liu Y C, Qian F, Zhou C, Zhang S C, Chen J M. Role of Hydrochar Properties on the Porosity of Hydrochar-based Porous Carbon for Their Sustainable Application. ACS Sustainable Chemistry \& Engineering, 2015; 3: 833-840.

[46] Li F Y, Gui X Y, Ji W C, Zhou C H. Effect of calcium dihydrogen phosphate addition on carbon retention and stability of biochars derived from cellulose, hemicellulose, and lignin. Chemosphere, 2020; 251: 126335. doi: 10.1016/j.chemosphere.2020.126335.

[47] Li F Y, Zimmerman A R, Hu X, Yu Z B, Huang J, Gao B, One-pot synthesis and characterization of engineered hydrochar by hydrothermal carbonization of biomass with $\mathrm{ZnCl}_{2}$. Chemosphere, 2020; 254: 126866 . doi: 10.1016/j.chemosphere.2020.126866.

[48] Li F Y, Duan F L, Ji W C, Gui X Y. Biochar-activated persulfate for organic contaminants removal: Efficiency, mechanisms and influencing factors. Ecotoxicology and Environmental Safety, 2020; 198: 110653. doi: 10.1016/j.ecoenv.2020.110653.

[49] Li F Y, Cao X D, Zhao L, Wang J F, Ding Z L. Effects of mineral additives on biochar formation: carbon retention, stability, and properties, Environmental Science \& Technology, 2014; 48: 11211-11217.

[50] Li F Y, Wang J F, Xie Y, Li H, Li X L, Li F R. Effects of pyrolysis temperature on carbon retention and stability of biochar. Transactions of the Chinese Society of Agricultural Engineering, 2015; 31: 266-271. (in Chinese).

[51] Zhao L, Cao X D, Mašek O, Zimmerman A R. Heterogeneity of biochar properties as a function of feedstock sources and production temperatures. Journal of Hazardous Materials, 2013; 256: 1-9.

[52] Ghanim B M, Pandey D S, Kwapinski W, Leahy J J. Hydrothermal carbonisation of poultry litter: Effects of treatment temperature and residence time on yields and chemical properties of hydrochars. Bioresource Technology, 2016; 216: 373-380.

[53] Danso-Boateng E, Shama G, Wheatley A D, Martin S J, Holdich R G. Hydrothermal carbonisation of sewage sludge: effect of process conditions on product characteristics and methane production. Bioresource Technology, 2015; 177: 318-327.

[54] Crombie K, Mašek O, Sohi S P, Brownsort P, Cross A. The effect of pyrolysis conditions on biochar stability as determined by three methods. Gcb Bioenergy, 2013; 5: 122-131.

[55] Liu Y X, Yao S, Wang Y Y, Lu H H, Brar S K, Yang S M. Bio-and hydrochars from rice straw and pig manure: inter-comparison. Bioresource Technology, 2017; 235: 332-337.

[56] Han X M, Wang F, Zhou B H, Chen H L, Yuan R F, Liu S H, et al. Phosphorus complexation of sewage sludge during thermal hydrolysis with different reaction temperature and reaction time by $\mathrm{P}$ K-edge XANES and ${ }^{31}$ P NMR. Science of the Total Environment, 2019; 688: 1-9.

[57] Reza M T, Lynam J G, Uddin M H, Coronella C J. Hydrothermal carbonization: Fate of inorganics. Biomass and Bioenergy, 2013; 49: 
86-94.

[58] Guo S Q, Dong X Y, Wu T T, Shi F J, Zhu C X. Characteristic evolution of hydrochar from hydrothermal carbonization of corn stalk. Journal of analytical and applied pyrolysis, 2015; 116: $1-9$.

[59] He C, Giannis A, Wang J Y. Conversion of sewage sludge to clean solid fuel using hydrothermal carbonization: hydrochar fuel characteristics and combustion behavior. Applied Energy, 2013; 111: 257-266.

[60] Guo Y, Bustin R M. FTIR spectroscopy and reflectance of modern charcoals and fungal decayed woods: implications for studies of inertinite in coals, International Journal of Coal Geology, 1998; 37: 29-53.

[61] Kemmou L, Frontistis Z, Vakros J, Manariotis I D, Mantzavinos D. Degradation of antibiotic sulfamethoxazole by biochar-activated persulfate: factors affecting the activation and degradation processes. Catalysis Today, 2018; 313: 128-133.

[62] Ouyang D, Chen Y, Yan J C, Qian L B, Han L, Chen M F. Activation mechanism of peroxymonosulfate by biochar for catalytic degradation of 1 , 4-dioxane: Important role of biochar defect structures. Chemical Engineering Journal, 2019; 370: 614-624.

[63] Zhao L, Cao X D, Zheng W, Kan Y. Phosphorus-assisted biomass thermal conversion: reducing carbon loss and improving biochar stability. PLoS
One, 2014; 9(12): e115373. doi:10.1371/journal.pone.0115373.

[64] Yang H P, Yan R, Chen H P, Lee D H, Zheng C G, Characteristics of hemicellulose, cellulose and lignin pyrolysis. Fuel, 2007; 86: 1781-1788.

[65] Wang T, Camps-Arbestain M, Hedley M. Predicting C aromaticity of biochars based on their elemental composition. Organic Geochemistry, 2013; 62: 1-6.

[66] Budai A, Zimmerman A R, Cowie A L, Webber J B W, Singh B P, Glaser B, et al. Biochar Carbon Stability Test Method: An assessment of methods to determine biochar carbon stability. Available: https://www.biochar-international.org/wp-content/uploads/2018/04/IBI Re port Biochar_Stability Test_Method_Final.pdf. [Accessed on 2021-02-07].

[67] Malghani S, Jüschke E, Baumert J, Thuille A, Antonietti M, Trumbore S, et al. Carbon sequestration potential of hydrothermal carbonization char (hydrochar) in two contrasting soils; results of a 1-year field study. Biology and Fertility of Soils, 2015; 51: 123-134.

[68] Kammann C, Ratering S, Eckhard C, Müller C. Biochar and hydrochar effects on greenhouse gas (carbon dioxide, nitrous oxide, and methane) fluxes from soils. Journal of Environmental Quality, 2012; 41: $1052-1066$. 


\section{Appendix}

Table S1 Properties of animal manure

\begin{tabular}{|c|c|c|c|}
\hline Properties & Chicken manure & Dairy manure & Swine manure \\
\hline Water content $/ \%$ & 8.59 & 9.74 & 5.83 \\
\hline Organic matter $/ \%$ & 20.12 & 18.40 & 22.31 \\
\hline $\mathrm{P} / \mathrm{g} \cdot \mathrm{kg}^{-1}$ & 8.13 & 5.44 & 26.31 \\
\hline $\mathrm{K} / \mathrm{g} \cdot \mathrm{kg}^{-1}$ & 26.14 & 3.02 & 6.35 \\
\hline $\mathrm{Na} / \mathrm{g} \cdot \mathrm{kg}^{-1}$ & 6.02 & 5.92 & 3.49 \\
\hline $\mathrm{Ca} / \mathrm{g} \cdot \mathrm{kg}^{-1}$ & 109.80 & 20.08 & 60.60 \\
\hline $\mathrm{Mg} / \mathrm{g} \cdot \mathrm{kg}^{-1}$ & 17.29 & 4.46 & 12.55 \\
\hline $\mathrm{Zn} / \mathrm{g} \cdot \mathrm{kg}^{-1}$ & 0.40 & 0.43 & 1.36 \\
\hline $\mathrm{Cu} / \mathrm{mg} \cdot \mathrm{kg}^{-1}$ & 60.24 & 61.41 & 317.20 \\
\hline $\mathrm{Pb} / \mathrm{mg} \cdot \mathrm{kg}^{-1}$ & 23.93 & 12.69 & 29.35 \\
\hline $\mathrm{Cd} / \mathrm{mg} \cdot \mathrm{kg}^{-1}$ & 0.28 & 0.45 & 15.23 \\
\hline
\end{tabular}

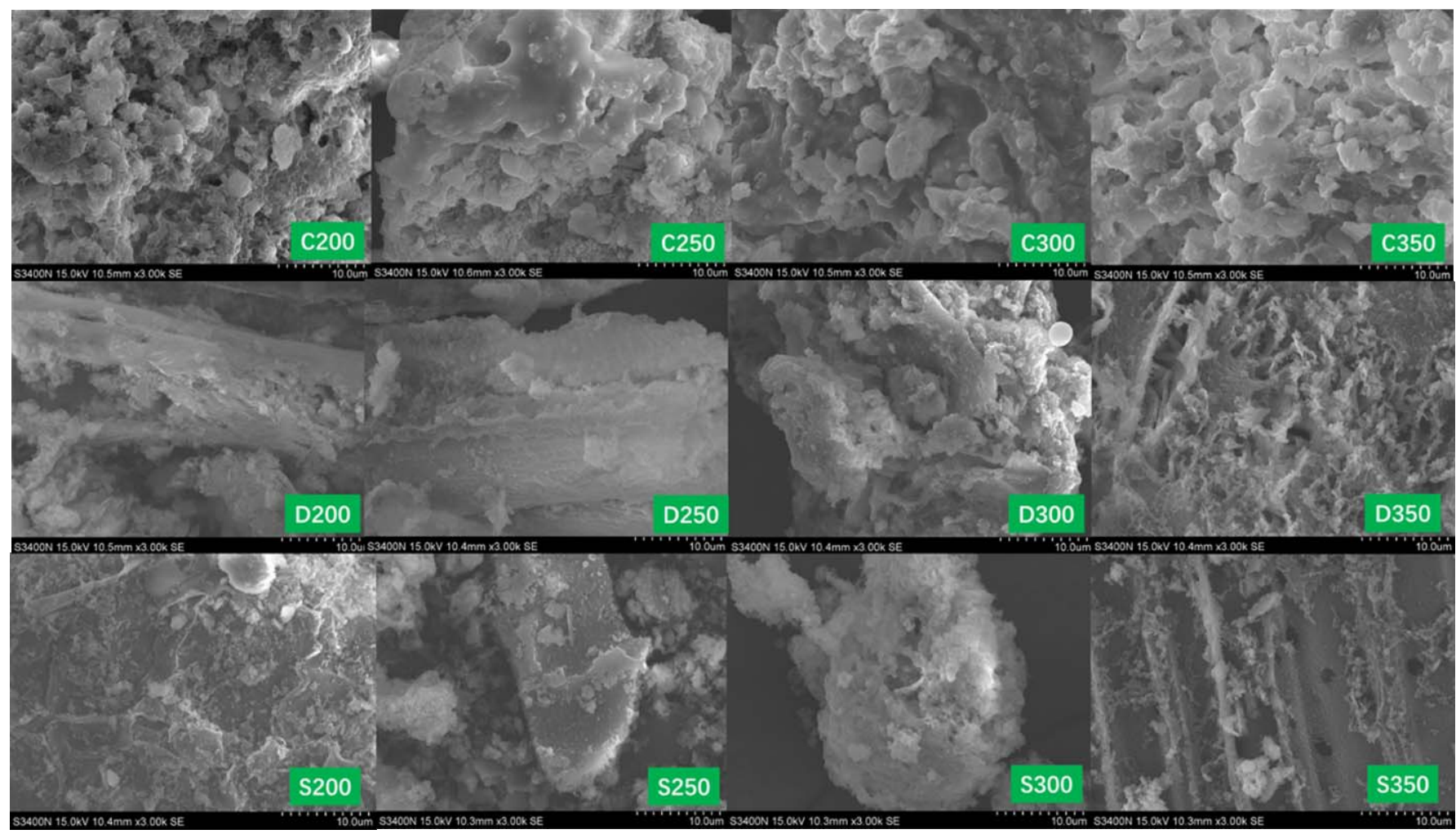

Figure S1 Scanning electron micrographs (SEM) images of hydrochar

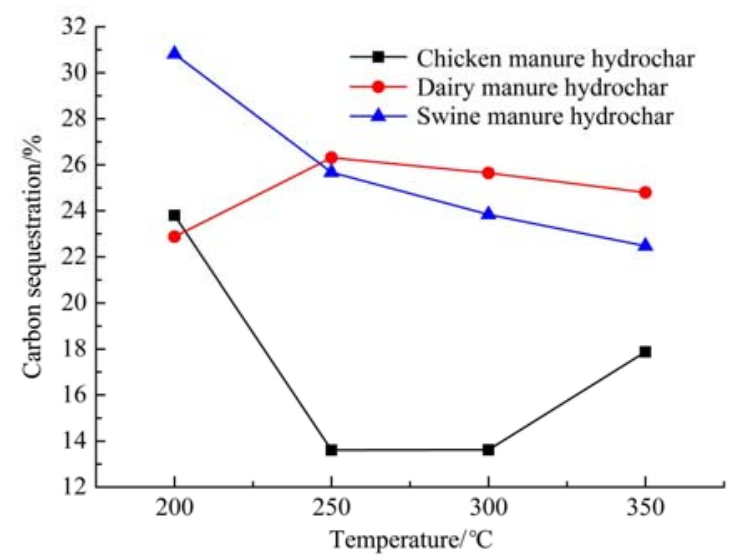

Figure S2 Effects of hydrothermal carbonization temperature on the carbon sequestration of animal manure hydrochar 